\begin{abstract}
A. Kaihe
PhD candidate. Graduate School of Core Ethics and Frontier Sciences. Ritsumeikan University, Japan, e-mail: gr0263sf@ed.ritsumei.ac.jp
\end{abstract}

\title{
A TRIO THAT MUST GO: CHANGING US-QING RELATIONS FROM 1868 TO 1882
}

Abstract. The Burlingame Treaty of 1868 opened new perspectives in diplomatic action for both the U.S. and the Qing Empire; however, 14 years later in 1882 The Chinese Exclusion Act prohibited Chinese laborers from entering the United States. Those two documents reveal, it seems, completely different political attitudes toward the Qing Empire on the part of the United States. The focus of this article is to understand the internal factors that lead the United States to successively adopt these two opposing policies. Constant changes in the domestic political and economic situation of the United States, I argue, have led to the adjustment of foreign policy with the Qing Empire. One caricature from the American satire cartoon magazine PUCK is used to illustrate important aspects of the lesser known history of the US-Qing relations from the 1860 s to the 1880s.

Key words: US-Qing Relations, Burlingame Treaty, Chinese Exclusion Act, Chinese Labor, GOP, PUCK, Taiping Rebellion, American society, late Qing Empire(1860-1880), "A Trio that Must Go".

\author{
А. Кайхе \\ PhD докторанты, Бейіндік этика және шекара ғылымдары Жоғары мектебі, \\ Рицумейкан Университеті, Жапония, e-mail: gr0263sf@ed.ritsumei.ac.jp \\ Кетуі керек трио: ақш-цин қарым-қатынасының (1868 жылдан 1882 жылға дейін өзгеруі)
}

Аңдатпа. 1868 жылғы Берлингейм келісімі АҚШ үшін де, Цин империясы үшін де Аипломатиялық әрекеттегі жаңа мүмкіндіктерді ашты, дегенмен 14 жылдан кейін, 1882 жылы Қытай заңы қытайлық жұмысшылардың АҚШ-қа шығуына тыйым салды. Бұл екі құжат Құрама Штаттар тарапынан Цин империясына мүлдем әртүрлі саяси көзқарастарды көрсетеді. Осы мақаланың мақсаты - АҚШ-тың осы екі қарама-қарсы саясатты дәйекті түрде қолдануға мәжбүр ететін ішкі факторларын түсіну. Мен Америка Құрама Штаттарының ішкі саяси және экономикалық жағдайындағы үнемі болатын өзгерістер Цин империясымен сыртқы саясаттың түзетілуіне әкелді деген оймен келісемін. PUCK мультфильмдері туралы америкалық сатиралық журналдың бір карикатурасы 1860 жылдан 1880 жылға дейін АҚШ пен Цин арасындағы қарымқатынастың аз танымал тарихының маңызды аспектілерін айқындау үшін қолданылады.

Түйін сөздер: АҚШ-Цин қарым-қатынасы, Бюрлингем келісім-шарты, Қытайдан шығарып тастау туралы заң, Қытайдың еңбек күші, Республикалық партия, Пакк, Тайпинг көтерілісі, Америкалық қоғам, Цин империясы (1860-1880), «A Trio that Must Go».

\author{
А. Кайхе \\ PhD докторант, Высшая школа профильной этики и пограничных наук, \\ Университет Рицумейкан, Япония, e-mail: gr0263sf@ed.ritsumei.ac.jp \\ Трио, которое Аолжно уйти: изменение отношений США-Цин с 1868 по 1882 гоА
}

Аннотация. СоглашениеБерлингеймаот 1868 года открылоновыеперспективывдипломатических Аействиях как Аля США, так и Аля империи Цин; однако спустя 14 лет, в 1882 году, китайский закон об исключении запрещал китайским рабочим въезд в Соединенные Штаты. Эти Ава документа Аемонстрируют совершенно разные политические взгляды на империю Цин со стороны СоеАиненных Штатов. Цель этой статьи - понять внутренние факторы, которые побуждают Соединенные Штаты последовательно применять эти Аве противоположные политики. Я утверждаю, что постоянные изменения во внутриполитическом и экономическом положении Соединенных Штатов привели к корректировке внешней политики с империей Цин. ОАна карикатура из американского сатирического журнала о мультфильмах PUCK используется Аля илмюстрации важных аспектов менее известной истории отношений межАу США и Цином с 1860-х по 1880-е годы.

Кмючевые слова: отношения межАу США и Цином, Аоговор Берлингейма, Закон об исключении из Китая, Труд китайцев, Республиканская партия, Пакк, Восстание тайпинов, Американское общество, Империя позднего Цин (1860-1880), «A Trio that Must Go». 
This article aims at showing that America's external policy towards the Qing Empire was not unified or guided by a single party line. Both Houses and succeeding presidents never had a unified political opinion on the Qing issue. Multiple international and domestic factors and parties conflicted to influence American decisions concerning the US-Qing relations (1860-1880). This article examines the main American factors and party struggles that became directly and indirectly related to the US-Qing relations from the Burlingame Treaty to the Chinese Exclusion Act. The caricature "A Trio that must go" suggest that domestic political pressure and struggles carried out by the Republicans from the postcivil war to the defeat of the 1882 elections were fundamental in the changed of policy towards the Qing and that the Chinese Exclusion Act was not so much aimed at the Qing government as a harsh diplomatic gesture as it was a response to domestic issues. Thus, the Chinese Exclusion Act was created as a byproduct of political struggles between Republican and Democrats that ultimately interfered with Republican diplomacy. A key point of this argument is that the Burlingame Treaty is a very strange treaty that seems, at first, to some extent inconsistent with the interests of the United States at that time.

PUCK was the best-selling full color satire cartoon magazine in the United States at the time. PUCK's editors and main caricaturists could catch the climate of public opinion, and make PUCK match the opinion of subscribers. It was a mainstream medium that, on the one hand, communicated American policy making to the public, and, on the other hand, could influence American policy making and political conflicts. There is no reason to believe that PUCK did not at times help shape subscribers' understanding of current circumstance and, function as propaganda for various political or economic goals. People always enjoy looking at and talking about visual art that has strong political flavor and the magazine's cartoons reveal the focus of political and social issues, including Chinese laborers, that most concerned American society. PUCK's caricatures thus offers important historical illustrations of different aspects of on-going historical developments in the United States.

As a typical political satire caricature, "A TRIO THAT MUST GO" which appeared on the cover of PUCK in September 1883, reflected the current political situation of the United States with three different figures. A Chinese man appears with two other figures arm in arm, one of which is the GOP elephant. This composition suggests that the Chinese problem has a close relation with the Republicans and that the Chinese problem was not an isolated political phenomenon in American society. Furthermore, the fact that the elephant stands in the middle of the image intimates that it was perhaps not Chinese labourers but the Republican Party itself that was the most serious problem. The caricaturist deliberately painted the elephant in elaborate details, suggesting that the Republican Party was the source of the problems.

Three figures walk hand in hand on a foggy night on a street where there is no one else, only two street lights in the background. As the title says, they have to go, and they are just leaving quietly. The three figures are an elephant, a Chinese man on the elephant's left hand, and a Church Bell represented as a crying lady (unless it is the other way around) on the right side of the elephant Who are they? Why do they appear together in this caricature? (Insert Figure 1 here)

\section{The Elephant}

The thin weak and crying elephant holds the bell lady's left hand with its right paw, standing on its two hind legs as a human in the centre of the caricature. Its whole body is scarred. This elephant has lost its two tusks which are broken, its head and left hind leg are wrapped in a bandage and blood is leaking out of the bandage on the leg. Its trunk is punctured, ripped open actually as there is a hole in the middle of the trunk. Moreover, the elephant wears a piece of cloth like traditional American Indian pants, which are called breechclout or breechcloth.

The injured elephant is labeled "Republican Party" and on its eye patch is written "Nov.1882". The Republican Party was already one of the two major political parties in the United States, with its historic rival, the Democratic Party. "Nov. 1882" refers to the Elections to the United States House of Representatives for the 48th Congress in $\mathbf{1 8 8 2}$ $\square$ Nov. 7 $\square$, which took place during President Chester A. Arthur's term. Arthur's Republican Party was badly defeated, losing its majority to the opposing Democratic Party after a campaign that focused on the resistance of Republican leaders to reforming the Spoils System (the practice that the winning political party would give civil services jobs to its supporters, friends and relatives after its election). After this election, President Arthur agreed with the Democrats to pass the Pendleton Civil Service Reform Act, establishing a professional civil service on January 16.

It seems clear that the cartoonist depicted a dejected bruised elephant to imply a serious political setback of the Republicans. However, when the "A 
TRIO THAT MUST GO” was published not only had the Democrats already won the election, but actually controlled the congress. In a sense the Republicans were already gone. So, the elephant in the caricature must represent not only the Republican Party, but also President Arthur himself. Arthur, a Republican President surrounded by the Democrats and mired in distress.

The Bell Lady

Holding the right paw of the elephant is a golden Church Bell shaped as a lady, unless it is a lady shaped as a Church Bell. She wipes her tears with a handkerchief and grieves, crying while her body leans backward. The clapper of the bell is covered by thick white cloth. The lady wears a white petticoat and her thin legs covered with striped stockings look quite weak to hold the weight of a large Church Bell. The crying lady is wearing on her head either a crown. It is hard to distinguish which it is.

I hypothesize that this figure represents Susan Brownell Anthony (1820-1906), an American social reformer and women's rights activist who played a pivotal role in the women's suffrage movement. In November 1869, she and others formed the American Woman Suffrage Association (AWSA). She began publicly supporting the Republican Party in the 1872 election. In 1878, Anthony and her partner arranged for Congress to be presented with an amendment giving women the right to vote. However, Anthony and her movement were not widely recognized and the amendment was defeated. Yet, she did not give up. By the 1880s, she was among the senior political figures in the United States. In 1883, she left the United States to go to Europe from February to November, to carry out the women's liberation movement and seek support (Harper 1898). Coincidentally, she was not in the United States when the caricature "A Trio that Must Go" was published on September 5, 1883. I suppose that the author of the caricature assumes that some people hoped that she would not come back. Anthony is popularly known for her contribution to the Nineteenth Amendment to the U.S. Constitution, passed in 1920, fourteen years after her death, which gives women the right to vote. In fact, the Nineteenth Amendment is the amendment that was originally introduced in Congress in 1878 by Senator Aaron A. Sargent, a Republican, at the instigation of Antony and her partner, but was defeated. Could this close relationship between Anthony and the Republican Party be reasonable ground for the elephant and crying lady to be holding hands together?

The crying lady seems thin and small to carry the big Church Bell which is her skirt. Generally, people connect the Church bell with the Liberty Bell. It is viewed as a symbol of the US government and of LIBERTY in American history. The clapper of the bell is wrapped in thick cloth, which doesn't entail that the bell cannot be heard at all, but that if it rings its sound at best will be muffled and unclear. That seems to reflect how Anthony's voice was limited by contemporary social opinion on feminism and women vote.

The bell is to strike for the Liberty of all who live in this land. If the people do not want or fail to hear the bell, what does it mean?

If the Bell lady is not Susan Brownell Anthony, we may nonetheless assume that it is the bell of liberty. Should we think that the ideas of democracy and liberty present from the outset of the United States' founding, were at that time, like a fragile lady being swept out the door? The Republican Party originally championed classical liberal ideas, including anti-slavery and economic reforms (Fornieri 2008). In addition, the bell of the American Revolution of Independence, was promoted by the political forces urging the abolition of slavery in 1830 which is in accordance with the governance plan of the Republican Party afterwards. Therefore, when the GOP elephant lost its power, it seems obvious that the Church bell that symbolized a central element of its policy agendas could also be excluded by the opposition party. Unlike Kurashige, I think that what is implied, is not the American public did not want to hear the bell of liberty, but that the Democrats did not want to hear it. When he describes this caricature, Kurashige adds "the third figure (the bell lady) embodies the simultaneous concern that the ringing of church bells was a public nuisance ..." (Kurashige 2016) However, Kurashige does not clarify what made the public feel uncomfortable about church bell's ringing, nor does he explain why the bell was painted as the dress of a weeping lady whose slender legs seem unable to support its weight.

The Chinese Man

On the left hand of the GOP elephant is a plain unpleasant or displeased looking Chinese man holding his bedding in his left hand. He wears a big black hat and typical Qing style southern Chinese casual wear. His boat-shoes inform us that he came from the south east coastal area of the Qing Empire. The Chinese man looks very depressed. What made it sensible for the author of this caricature to think that the two other figures of the American politics of 1883 like the Chinese had to go? Let us first see why the Chinese must go?

"The Chinese must go" was a popular slogan, before and after the Chines Exclusion Act was 
signed it was used frequently. This slogan was first advocated by the California's workers' party in the 1870 s, and then spread throughout the country. Excluding Chinese was equivalent to being opposed to Republican governance. The Chinese Exclusion slogan became a political means for anti-Republican forces to gain support. After the Republican Party was defeated in the general election of 1882 , the attack on the Republican Party became more straightforward. The three characters of the satirical caricature, "A Trio that must go", are clearly a fallen "Republican Trio". The caricature blames on the GOP elephant the Chinese laborers' problems and unanswerable questions of justice and freedom (the bell lady). Implied is the idea that the Republican Party has caused these social problems and the ruling crisis. Therefore, their three images are bundled together under the unwelcome label: "A Trio that must go."

\section{Burlingame and the Burlingame Treaty}

The US first signed the Wang-Xia Treaty (1844) for trade with Qing. At that time the US had already started to do business with Qing through the Canton system (In 1681, the Elhe Taifin era. Qing opened 7 ports for international trade. Later in 1757, 6 of these were closed by the emperor Abkai Wehiyehe). It was not a large-scale partner and did not trade significantly with the Qing until the end of the Civil War (1861-1865). However, during the Second Opium War, in 1858, in order to attack Guangzhou City, two US warships, the Portsmouth and Levante, launched a landing attack on the four fortresses of the Pearl River Estuary. During that time, the United States participated in the British artillery attack on the Pearl River estuary fortifications and profited together with other powers from the Tianjin Treaty. Since then, the American society's attitude towards Chinese has been far from ideal, as Haiming Liu described it: "In the first half of the 19th century, Americans were keenly interested in Chinese merchandise and culture, and held China and Chinese people in great respect." (Liu 2003) At the time, American merchants did promote the various commodities of the Qing Empire to the American customer base dominated by the middle class. However, this kind of trade does not positively influence the attitude of American society toward the Qing Empire and the Chinese.

Thus, the US began formal diplomatic relations with the Qing Empire later than other major powers. However, in spite of its participation in the Pearl river attack, the US did not formally make war with Qing as did Britain, Germany, France, Russia and Japan. The US pursued through diplomatic negotia- tions with major powers its interest on the issues of the Qing Empire.

On the brink of the Civil War, in 1861, under the orders of Secretary of State William Seward, Anson Burlingame was appointed new minister to the Qing Empire. His mission was to establish the United States as a power in the East. Burlingame worked earnestly to carry out the idealistic sentiments expressed in the Wang-Xia Treaty, and he argued for cooperation with the Qing government. He repeatadly asserted that the United States, unlike other major powers, would respect the integrity of its international legal commitments. His first biographer cast Burlingame's view of his diplomatic duties "as an embodiment of the true missionary spirit" (Williams 1912) and Burlingame himself chided missionaries who continued to follow their European brethren in supporting the use of force in the Qing Empire as failing to live up to their own ideals.( Kroncke 2019)

At that time the Taiping Rebellion (1851-1864) and its regime controlled the south part of the Original China Region. Burlingame saw the Taiping Rebellion as an opportunity for the US to develop closer diplomatic relations with the Qing Empire and emphasized the role of the US in preserving the Qing's territorial integrity. As Burlingame put it: "policy substituted for the old doctrine of violence, one of fair diplomatic action; so that if a Consul and the Taotai [the local Chinese o $\square$ cial responsible for foreign relations] could not agree, before war should ensue, it should be referred to Pekin and hence, to the home governments. That policy was ... an agreement upon the part of the representatives of the Western powers that they would not interfere in the internal a $\square$ airs of China; would give to the treaties a fair and Christian construction; that they would abandon the so-called concession doctrine, and that they never would menace the territorial integrity of China." (Schrecker 2010) Burlingame's unique diplomatic attitude made the Qing government realize that the United States could be an important intermediary for improving foreign diplomacy. His attitude encouraged a convergence of the United States and the Qing dynasty's diplomatic interests. Burlingame's attitude, which was very different from that of other western powers" representatives led him to be later on appointed by the Qing court as fullfledged ambassador to the West.

The Burlingame Treaty or Burlingame-Seward Treaty which was signed in 1868 affirmed the Qing's sovereignty while encouraging Chinese immigration to the United States. Critically, this treaty also reinforced the right of US missionaries to work freely in 
the Qing Empire. The article 8 of the treaty offered Qing some protection from external influence in internal matters. In this final article of the treaty, the U.S. recognized that the decision to begin new construction projects or similar improvements belonged to the Qing government, not to foreign powers or their representatives. This point was intended as a safeguard against undue U.S. involvement in Qing's domestic affairs. (Bevans 1971) The treaty was written very clearly. In order to gain a place in East Asia, the Republican Party gave the Qing Empire a posture of equal reciprocal diplomacy, to make closer relationships with the Qing, and to balance the influence of other powers. (see annex 1)

Surprisingly in view of what was to happen later, of what was to become the main reason for demanding the exclusion of Chinese from the U.S. the American government may apparently have already known when it signed the Treaty that there was a surplus of Chinese labor in the US. So, what made it sign the Burlingame Treaty, when the decision seems to some extent to the disadvantage of the federal government? There may have been many reasons.

One was that the Republican Party government expected to make a powerful Asian ally of the Qing after the civil war period, and saw the Empire as a central element of its new foreign policy in Asia Pacific. For the Republican government, the Chinese labor issue was used by the Democrats to attack the GOP's foreign policy, but the US-Qing relations were different from the Chinese issue inside the U.S. which was mainly seen as a problem fomented by the Democrats.

Another reason perhaps is that Burlingame was a Western diplomat who was concerned by the Qing Empire's fate. Western diplomats who like him cared for the fate of the Qing Empire were very few. His status as a US diplomat made it possible for him to use diplomacy to maximize the pursuit of diplomatic interests for the Qing Empire. Therefore, the treaty was successfully signed because of a talented negotiator well disposed towards the Qing Empire.

Furthermore, the U.S. government realized that post-war reconstruction would require a large amount of imported labor. Even if, or perhaps because there already was a considerable number of Chinese laborers working in the United States, the Americans may have thought that Chinese laborers would not flood into the United States.

Finally, and more importantly, in order to quickly restore and expand its international political influence after the end of the civil war, the United States chose to compete with other powers in East
Asia. Aligning with the Qing and assisting the Qing Empire national strength were the Republican Party's Asian foreign policy at the time. Unlike other powers' ruthless military actions against the Qing, the Republican Party pursued an equal and friendly diplomacy in order to win the Qing, as an ally. Therefore, the Burlingame Treaty is a move in the Republican Far East diplomatic strategy. Compared with the Chinese laborers problem, this crucial diplomatic move was very important.

Though it was signed by a Democrat president, Johnson, beginning with Grant who became president in 1869 , and the coming four U.S. presidents up to 1885 were all Republicans.

American economic development, Chinese labourers and violent unrest

Chinese labourers first largely emigrated to the US to work during the Gold Rush (1848-1855), soon after California was ceded to the United States in 1848 at the end of the Mexican-American War (1846-1848). In addition, when the United States obtained California from Mexico, a small number of Chinese had already settled in Southern California. However, I cannot confirm how many Chinese workers were legally admitted or had a legal status in the US. Many thousands South Chinese emigrated to America after 1851, during the Taiping Rebellion. Most of them preferred to return after the suppression of the Taiping Rebellion in 1864. Labor shortage appeared again in 1864, but after the completion of the first trans-continental railroad construction in September 1869 there were no more work opportunities for Chinese emigrants just one year after the Burlingame Treaty.

Two companies competed to get the most land and money during the Reconstruction Era: Union Pacific (built tracks from East to West) and Central Pacific (built tracks from West to East). Chinese labourers were a vital resource for constructing the railroad of the west line. Fifty thousand Chinese labourers were hired by the Central Pacific Railroad in February 1865. The Civil War ended on May 9, 1865, yet nobody knew beforehand when the war would actually finish. As a large number of American men served in the army, the federal government needed foreign labour to make up for a serious shortage of labour and to begin reconstruction. Soon, more and more Chinese men were hired. Working conditions were harsh in the west part of the continental railroad, and Chinese people were compensated less than their white counterparts.

It is clear that the United States needed these migrant labourers for Reconstruction. However, following the completion of the transcontinental 
railroad, Central Pacific Rail Road didn't need the Chinese any more and with the cooling of reconstruction, there was no longer a major demand for Chinese labourers in the American West, but the US government did not have any effective plan to evacuate or repatriate them, so, they naturally looked for opportunities to survive locally. They were looking for any available jobs in town, while many local Americans and European immigrants were reluctant to do dirty and low-paying jobs.

The combination of less work and more people looking for work fuelled fierce job competition between Chinese immigrants and white Americans, especially Irish and German immigrants. Resentment toward Chinese labourers was rooted in their willingness to accept lower wages, as a consequence of which Chinese workers still had a lot of job opportunities. This made the local and new comers whites resent the Chinese people. They believed that the Chinese stole jobs and were the reason why there was a large number of unemployed whites.

Local Exclusion and Annexes of the Burlingame Treaty.

Eventually, the situation started to deteriorate. Whites began to violently attack Chinese and Chinese settlements. This kind of folk violence broke out from the beginning of the 1870 s to the end of the 1880s. The Chinese Massacre of $\mathbf{1 8 7 1}$ was a typical racially motivated riot which occurred on October 24, 1871 in Los Angeles, California. A mob of around 500 white rioters entered Chinatown to attack, rob, and murder Chinese residents. An estimated 20 Chinese immigrants were tortured and then hanged by the mob, making the event the earliest mass lynching in American history. It was just the beginning; most vicious massacres occurred in the 1880s after the official adoption of the Bill.

The anti-Chinese movement was a direct violent reaction to the underlying workers' crisis of survival. Strictly speaking, this violence did not bring about any qualitative change in the employment rate and salary of white workers. If capitalists did not sympathize with the Chinese people, neither did they have mercy for white labourers. The only gesture of the US government was to pass a series of bills to alleviate the plight of the economic downturn in an attempt to eliminate the dissatisfaction that led to the exclusion. Most Chinese moved or fled to the Mexico after 1882. (Camacho 2009)

The earliest anti-Chinese bill, The Pigtail Ordinance, was an 1873 law to force prisoners in San Francisco, California, to have their hair cut within an inch of the scalp. It affected Chinese prisoners in particular, as it meant they would have their queue cut off. The proposal passed by a narrow margin through the San Francisco Board of Supervisors in 1873. An identical version of the law, enacted in 1876, was struck down as unconstitutional in 1879.

During the 1870 s, there were repeated efforts in the United States Congress to limit Chinese immigration. One result of efforts in this direction is the Page Act of 1875, which forbade the migration of women believed to be inclined to engage in prostitution and anybody coming to the United States as a forced labourer. The Act did not significantly curtail the flow of mostly male forced Chinese labourers. This Act was the first restrictive federal immigration law and prohibited the entry of immigrants considered "undesirable." The law classified as "undesirable" any individual from Asia who was coming to America as a forced labourer, any Asian woman who would engage in prostitution, and all people considered to be convicts in their own country.

This law was named after its sponsor, Representative Horace F. Page, a Republican who introduced it to "end the danger of cheap Chinese labour and immoral Chinese women". During the 47th United States Congress (1873-1883), he was the chairman of the Committee on Commerce. (Biographical Directory of the United States Congress, 1774-Present) The Page Act was supposed to strengthen the ban against Chinese labourers, by imposing a fine of up to $\$ 2,000$ and a maximum jail sentence of one year upon anyone who tried to bring a person from China, Japan, or any other Asian country to the United States. However, these provisions, as well as those regarding convicts "had little effect at the time". Relations between Chinese labourers and American labourers were further strained as unemployment rose dramatically in the years after the Panic of 1873 , reaching around 14 percent by 1876 .

In 1877, steep wage cuts led American railroad workers to launch the Great Railroad Strike. This stopped trains all across the country. In July 1877 , the market for lumber crashed as well, it send several leading Michigan lumbering concerns into bankruptcy. Within a year, the effects of this second business slump reached all the way to California. The depression lifted in the spring of 1879 , but tension between labourers and the leaders of banking and manufacturing interests lingered on.

\section{Party Struggle and Policy Making}

Poor economic conditions caused voters to turn against the Republican Party. In the 1874 congressional elections, the Democrats assumed control of the House. Public opinion made it difficult for President Grant administration to develop a coherent policy regarding the Southern states. The North began 
to steer away from Reconstruction. With the depression, ambitious railroad building programs crashed across the South, leaving most states deep in debt and burdened with heavy taxes. Retrenchment was a common response of southern states to state debts during the depression. One by one, each Southern state fell to the Democrats, and the Republicans lost power.

During the Great Railroad Strike, anti-Chinese riots broke out in San Francisco, and a third party, the Workingman's Party, was formed with an emphasis on stopping Chinese immigration. California became a hotbed for violence, where mobs of white vigilantes entered the city of San Francisco and mining encampments to lynch, rob, and torch the homes of the Chinese migrant labourers. The party took particular aim against cheap Chinese immigrant labour and the Central Pacific Railroad which employed them. Its goal was to "rid the country of Chinese cheap labour" and its famous slogan was "The Chinese must go!" The party leader Kearney's attacks against the Chinese were of a particularly virulent and openly racist in nature. They found considerable support among white Californians at the time.

The first bill to significantly curtail Chinese migration that passed both houses of Congress was the Fifteen Passenger Bill of 1879. The bill forbade sea vessels from bringing in more than fifteen Chinese passengers in any single voyage to the United States. Ship masters were required to present a sworn list of all Chinese passengers upon arrival, and violators could be fined $\$ 100$ and six months in prison. President Hayes vetoed the bill, believing that the United States should not abrogate treaties without negotiation. The veto drew praise among eastern liberals. However, Hayes was bitterly denounced in the West. In the subsequent furore, Democrats in the House of Representatives attempted to impeach him, but narrowly failed when Republicans prevented a quorum by refusing to vote. After the failed vote, Assistant Secretary of State Frederick W. Seward suggested that both countries should work together to reduce immigration, and with James Burrill Angell he negotiated with Qing diplomats to find a solution.

Hayes sent a commission led by Angell to Qing to negotiate what became the Angell Treaty (1880) (Salyer 2006) allowing restrictions on Chinese immigration. On November 17, 1880, the new treaty was signed in Beijing. According to it the United States would temporarily suspend immigration of skilled and unskilled labourers from Qing, while still allowing the immigration of white-collar professionals. The treaty also reaffirmed the United
States' continuing commitment to protect the rights and privileges of Chinese labourers already present in the United States.

According to the content of these two treaties, we see that President Hayes's aim was to renew but to maintain the same overall perspective in relations with the Qing. Hayes's government sought to ease the tension among various domestic forces through a reasonable and lawful route. At the same time, his government tried to work together with the Qing government to solve the problem of excess Chinese labourers through consultation and agreement.

Two years later, It is Horace F. Page, who once again submitted this time the H.R. 5804 motion to the House of Representatives on April 12, 1882, which is also known as the Chinese Exclusion Act. The act committee consideration by the House Foreign Relations passed the house on April 17. Soon later, it passed the Senate on April 28, 1882 with amendment. Finally, the House agreed to the Senate amendment on May 3, 1882, and it was signed into law by President Chester A. Arthur on May 6, 1882. Most of the protections for Chinese immigrants that previous treaties had secured were reversed by Congress in the Chinese Exclusion Act of 1882. (See annex 2) The Chinese Exclusion Act excluded Chinese labourers from the country under penalty of imprisonment and deportation. It also made Chinese immigrants permanent aliens by excluding them from U.S. citizenship. The Exclusion Act, along with the restrictions that followed it, froze the Chinese community in place in 1882 , and prevented it from growing and assimilating into U.S. society as European immigrant groups did.

The original intention and content of the first two treaties - the Burlingame and the Angell Treaties are very different from the Chinese Exclusion Act. The Chinese Exclusion Act is arbitrary and tough. The two treaties pursued collaboration and mutual understanding. The Chinese Exclusion Act was in contradiction with the content of the two treaties, it indicated the clear dominance of domestic concerns over foreign policy, not surprisingly as it is an act of Congress, not a treaty.

It is clear that the victory of the civil war gave the Republicans many advantages in governing. However, with the passage of time, the short-term reconstruction had not fundamentally brought about a real recovery of the U.S. economy. Since the Republican Party failed to effectively resolve the economic recession and the Chinese labor problem it engendered during the following ten years, the Democratic Party took the opportunity to continuously expand its influence in the two chambers and 
eventually won the 1882 general election. The Burlingame Treaty was actually based on the Republican Party's goodwill diplomacy strategy to balance the excess power of the great Powers in their relation with the Qing Empire.

Chinese Labourers and the US-Qing relations

After 1868, the US government issued four additions and modifications (The Pigtail Ordinance 1873, Page Act of 1875, Fifteen Passenger Bill of 1879, Angell Treaty 1880.) to the Burlingame Treaty that all strengthened restrictions on Chinese immigration. Their purpose was to address the domestic issues that ultimately led to the Exclusion Act. The Chinese Exclusion Act cannot be considered alone if we want to understand and interpret the attitude and policy of the U.S. government towards Chinese labourers and the Qing Empire. Before and after the signing of the bill, the U.S. government always tried to protect the personal safety of the Chinese as far as possible in spite of the anti-China riots. In addition, despite the repatriation of some Chinese workers, others were able to stay in the United States. Moreover, throughout the time when the treaty and its successive annexes were signed a limited number of Chinese workers was allowed to enter the United States territory every year by the federal government.

According to the original documents of the Library of Congress, the two parties long debated in the two houses the formulation of the Chinese Exclusion Act and its subsequent amendments. The Republican Party did not want exclusion issues to interfere with its diplomatic strategy in the Far East and it did not want to be held hostage and attacked by the opposition parties in reason of the Chinese labourer question. The electorate can be easily shaken, but the Republican Party was not willing to have its hands tied by the opposition party because of the issue of exclusion. The Chinese Exclusion issue was only a pawn for the two parties. It is true that it was presented by H. F. Page, a Republican, but apart from the fact that party discipline was not then what it has become, it may well be that it was a form of damage control, preventing the Democrats from presenting a Bill that was even more anti-Chinese.

As Kurashige argues, the Chinese Exclusion movement was not a simple issue. The Chinese Exclusion movement was a bargaining chip for the political parties. Unsurprisingly, the US government did not maintain a consistent attitude toward the Chinese labourers' problem. The real issue at the heart of the Exclusion Act was the party struggle in the United States over and above the interest groups that either needed or resented Chinese workers.

Although the Qing government made some diplomatic protests to the United States in relation to the Exclusion Act, in their relations the governments of the two countries did not seem to care too much about the issue which they viewed as rather minor and irrelevant. This is because the U.S. government strictly limited the number of Chinese labourers who would come to the United States each year. In addition, it should be noted that the ruler of the Qing Empire were Manchus, and foreign affairs involving migrant workers from the coast were far less important than the threat posed by the riots that broke out in the Qing Empire at the time or by the demands of the great powers.

\section{Coda: A Trio that Must Go}

There is a saying in the U.S. called bad news come in three. So, this Trio is deliberately tied together, in this way, it can give readers a sense of disgust. "A Trio that must go" appears quite clear on the surface; however, it contains much background information. Does the caricature indicate who the instigator is? What caused the exclusion and why all three must go? My analysis of the relations among the members of this Trio emphasizes that this political satire suggests what the political factor behind the exclusion is: party struggle.

As the date of publication of the caricature indicates, the public opinion in the United States increased in its efforts to stigmatize China after the "Chinese Exclusion Act" was passed. At the time, not only Puck, but all other media were frequently publishing content related to exclusion. The promulgation of the bill became a catalyst for the antiChinese movement of the American society.

The Republican Party and Chinese labourers, also the Bell lady all must go. The Chinese labourers' problem was used by the two major parties politicians as election chips. Ultimately, Chinese labourers inside of the U.S. were to become direct victims of American politics. When the Republican Party lost power in the 1882 election, The public media began to create various trends, this trio deliberately linked by the cartoonist, made people feel that these three were associates responsible or illustrative of the problems besetting America.

\section{Annex 1: The Burligame Treaty \\ The Burlingame Treaty-1868}

- Recognized China's right of eminent domain over all of her territory.

Gave China the right to appoint consuls at ports of the United States, who shall enjoy the same privileges and immunities as those of Great Britain and Russia. 
Provided citizens of the United States in China of every religious persuasion and Chinese subjects in the U.S. to enjoy the entire liberty of conscience and to be exempt from disability or persecution on account of their religious faith or worship in either country.

Granted certain privileges to citizens of either country residing in either country the privilege of naturalization....

\section{an American Diplomat}

Stanton Jue. Anson Burlingame,

Article VIII

"The United States, always disclaiming and discouraging all practices of unnecessary dictation and intervention by one nation in the affairs or domestic administration of another, do hereby freely disclaim and disavow any intention or right to intervene in the domestic administration of China in regard to the construction of railroads, telegraphs or other material internal improvements. On the other hand, his Majesty, the Emperor of China, reserves to himself the right to decide the time and manner and circumstances of introducing such improvements within his dominions. With this mutual understanding it is agreed by the contracting parties that if ..."

Annex 2: The Exclusion Act

Chinese Exclusion Act

May 6, 1882

(U. S. Statutes at Large, Vol. XXII, p. 58 ff.)

An act to execute certain treaty stipulations relating to Chinese.

WHEREAS, in the opinion of the Government of the United States the coming of Chinese laborers to this country endangers the good order of certain localities within the territory thereof: Therefore,

Be it enacted, That from and after the expiration of ninety days next after the passage of this act, and until the expiration of ten years next after the passage of this act, the coming of Chinese laborers to the Untied States be, . . . suspended; and during such suspension it shall not be lawful for any Chinese laborer to come, or, having so come after the expiration of said ninety days, to remain within the United States.

SEC. 2. That the master of any vessel who shall knowingly bring within the United States on such vessel, and land or permit to be landed, any Chinese laborer, from any foreign port or place, shall be deemed guilty of a misdemeanor, and on conviction thereof shall be punished by a fine of not more than five hundred dollars for each and every such Chinese laborer so brought, and may be also imprisoned for a term not exceeding one year.

SEC. 3. That the two foregoing sections shall not apply to Chinese laborers who were in the United
States on the seventeenth day of November, eighteen hundred and eighty, or who shall have come into the same before the expiration of ninety days next after the passage of this act,...

SEC. 6. That in order to the faithful execution of articles one and two of the treaty in this act before mentioned, every Chinese person other than a laborer who may be entitled by said treaty and this act to come within the United States, and who shall be about to come to the United States, shall be identified as so entitled by the Chinese Government in each case, such identity to be evidenced by a certificate issued under the authority of said government, which certificate shall be in the English language or (if not in the English language) accompanied by a translation into English, stating such right to come, and which certificate shall state the name, title, or official rank, if any, the age, height, and all physical peculiarities former and present occupation or profession and place of residence in China of the person to whom the certificate is issued and that such person is entitled conformably to the treaty in this act mentioned to come within the United States. ...

SEC. 12. That no Chinese person shall be permitted to enter the United States by land without producing to the proper office of customs the certificate in this act required of Chinese persons seeking to land from a vessel. Any any Chinese person found unlawfully within the United States shall be caused to be removed therefrom to the country from whence he came, by direction of the President of the United States, and at the cost of the United States, after being brought before some justice, judge, or commissioner of a court of the United States and found to be one not lawfully entitled to be or remain in the United States.

SEC. 13. That this act shall not apply to diplomatic and other officers of the Chinese Government traveling upon the business of that government, whose credentials shall be taken as equivalent to the certificate in this act mentioned, and shall exempt them and their body and household servants from the provisions of this act as to other Chinese persons.

SEC. 14. That hereafter no State court or court of the United States shall admit Chinese to citizenship; and all laws in conflict with this act are hereby repealed.

SEC. 15. That the words "Chinese laborers," whenever used in this act, shall be construed to mean both skilled and unskilled laborers and Chinese employed in mining.

Annex 3: Timeline of Chinese Immigration and Exclusion Bills 
During the period from the 1860 s to the 1880 s, of the four American presidents; $(\mathbf{D}=$ Democratic Party. $\mathbf{R}=$ Republican Party/GOP.)

Andrew Johnson (1865-1869.D),

Ulysses S. Grant (1869-1877.R),

Rutherford B. Hayes (1877-1881. R),

Chester A. Arthur (1881-1885. R).

Three are Republicans. The Republican Party was the ruling party from 1869 to 1885 . It nonetheless was unable to revive the economy and quell domestic economic crises. This resulted in the loss of a large number of supporters, and the majority in both houses of Congress was won by the Democratic Party in 1882 and the power of the Republican Party was greatly reduced.

\section{Timeline}

1848. Gold is discovered at Sutter's Mill, California. many Chinese arrive to mine for gold.

1850. Foreign Miners' tax mainly targets Chinese and Mexican miners.

1852. Approximately 25,000 Chinese working in America.

1854. Court rules that Chinese cannot give testimony in court.

1862. Chinese Consolidated Benevolent Association forms.

1865. Central Pacific Railroad recruits Chinese workers; ultimately employs about 15,000 Chinese workers.
1868. Burlingame Treaty.

1869. First transcontinental railroad completed. The Black Friday panic.

1870. California passes a law against the importation of Chinese and Japanese women for prostitution.

1871. Los Angeles: anti-Chinese violence; 18 Chinese killed.

The Chicago Fire. Chinese Massacre on October 24, 1871 in Los Angeles.

1872. The outbreak of Equine Influenza.

1873. The Pigtail Ordinance. Panic of 1873. Start of major economic downturn that last through the decade; blamed on corrupt RR companies. San Francisco Board of Supervisors. Demonetization of silver.

1875. The Page Act.

1877. Chico, CA's anti-Chinese violence.

1878. Court rules Chinese ineligible for naturalized citizenship.

1879. Fifteen Passenger Bill

1880. Angell Treaty. Approximately 106,000 Chinese in America; California passes antimiscegenation law (no interracial marriage).

1882. Chinese Exclusion Act: prohibits Chinese immigration (in one year, Chinese immigration drops from 40,000 to 23 ).

1885. Rock Springs Wyoming Anti-Chinese Violence.

1892. Geary Act-extends Chinese Exclusion Act.

\section{References}

Bevans, Charles Irving. 1971. Treaties and Other International Agreements of the United States of America1776-1949. Washington D.C. Department of State Publication 8549: 683.

Blair, William. 2005."The Use of Military Force to Protect the Gains of Reconstruction." Civil War History. 51 (4). : 388-402.

Brown, Thomas J. 2006. Reconstructions: New Perspectives on Postbellum America. essays by 8 scholars excerpt and text search. New York: Oxford University Press. : 76-128.

Burlingame's speech, Boston, 21 Aug. 1868; Boston Post, 22 Aug. 1868, 3; and O $\square$ cial Papers of the Chinese Legation. Berlin: S. Calvary \& Co., 33.

Chinese Exclusion Act. FORTY-SEVENTH CONGRESS. 1882. SESS. I. CH. 117-120,126.

https://www.loc.gov/law/.../47thcongress/session.../c47s1ch126.pdf (accessed February 5, 2019)

Douglas R Egerton. 2014. The Wars of Reconstruction: The Brief, Violent History of America's Most Progressive Era. New York: Bloomsbury Press. : 131.

Downs, Gregory P. 2015.After Appomattox: Military Occupation and the Ends of War. Cambridge: Harvard University Press. : 3 .

Graetz F. 1883. “A Trio that Must Go.” New York: Keppler \& Schwarzmann. http://www.loc.gov/pictures/item/2012645510/ (accessed February 5, 2019)

Gold, Martin B. 2012, Forbidden Citizens: Chinese Exclusion and the U.S. Congress: a Legislative History. Alexandria, VA. The Capitol.Net, Inc.:503-15.

Harper, Ida Husted (1898-1908). The Life and Work of Susan B. Anthony in three volumes. Indianapolis: Hollenbeck Press. Vols.1 and vol. 2, 1898; vols.3, 1908. Vol. 2, pp. 546, 578-79

Kroncke, Jedidiah Joseph. 2016. The Futility of Law and Development: China and the Dangers of Exporting American Law. Oxford University Press: 80.

Kurashige, Lon. 2016. Two Gaces of Exclusion, The Untold History of Anti-Asian Racism in the United States. Chapel Hill, The University of North Carolina Press: 112.

Liu,Haiming. 2003. Chinese Exclusion Laws and the U.S.-China Relationship. Pomona: California State Polytechnic University: 151. 
Salyer, Lucy. 2006. Chew Heong v. U.S.: Chinese Exclusion and the Federal Courts.Federal Judicial Center, Feceral Judicial History Office: 3,5,14,28,30,38.https://www.fjc.gov/history/famous-federal-trials/chew-heong-v.-u.s.-chinese-exclusion-and-federal-courts (accessed February 5, 2019)

Schrecker, John. 2010. "For the Equality of Men-for the Equality of Nations: Anson Burlingame and China's First Embassy to the United States." 1868. Journal of American-East Asian Relations 17.1. : 9-34.

Scott, David. 2008. China and the International System, 1840-1949: Power, Presence, and Perceptions in a Century of Humiliation. Albany, NY. State University of New York Press: 77.

\section{Bibliography}

Anderson, David L. 1979. Anson Burlingame: Reformer and Diplomat. Civil War History 25. Chicago: The Kent State University Press.

Annex 1: The Burlingame Treaty

http://www.unc.edu/depts/diplomat/item/2011/0912/ca/jue_burlingame.html (accessed February 5, 2019)

Annex 2: The Exclusion Act

http://www.pbs.org/weta/thewest/resources/archives/seven/chinxact.htm

Barnes, William H. 1868. "History of the Thirty-ninth Congress of the United States." Summary of Congressional activity. New

York: Harper \& brothers.

Biographical Directory of the United States Congress, 1774-Present. PAGE, HoraceFrancis,1833-1890. http://bioguide.congress.gov/scripts/biodisplay.pl?index=P000017 (accessed February 5,2019)

Blum, Edward J. 2005. Reforging the White Republic: Race, Religion, and American Nationalism, 1865-1898.Baton Rouge: Louisiana State University Press.

Brownstone, David M. 1988. The Chinese-American Heritage. New York. Facts on File.

Burlingame Public Library https://www.burlingame.org/library/

(accessed February 5, 2019)

Burlingame Family Papers, Library of Congress.1810-1922.

https://catalog.loc.gov/vwebv/search?searchCode=LCCN\&searchArg=mm\%2078014373\&searchType=1\&permalink=y

(accessed February 5, 2019)

Burlingame-Seward-Treaty https://history.state.gov/milestones/1866-1898/burlingame-seward-treaty

(accessed February 5, 2019)

CAMACHO, JULIA MARÍA SCHIAVONE.2009. Crossing Boundaries, Claiming a Homeland: The Mexican Chinese Transpa-

cific Journey to Becoming Mexican, 1930s-1960s. Pacific Historical Review, Vol. 78, No. 4, pages 545-577.

Donald, David H. et al. 2001. Civil War and Reconstruction. New York: Norton.

Eric Foner and Olivia Mahoney. 1995. America's Reconstruction: People and Politics after the Civil War. Harper Perennial.

Eric Foner. 2005. Forever Free: The Story of Emancipation and Reconstruction. New York: A Division of Random House, Inc.

Eric Foner. 2014. Introduction to the 2014 Anniversary Edition, in Reconstruction: America's Unfinished Revolution, 1863-

1877. New York: Harper Perennial. Section 1, module 2, Future directions.

Ford, Lacy K. 2005. A Companion to the Civil War and Reconstruction. Oxford. Wiley Blackwell. : 518.

Franklin, John Hope. 1961. Reconstruction after the Civil War. Chicago: University Of Chicago Press, 2nd edition.

Frantz, Edward O. 2014. A Companion to the Reconstruction Presidents 1865-1881. 30 essays by scholars. West Sussex, UK:

Wiley Blackwell.

Frederick Wells Williams. 1912. Anson Burlingame and the First Chinese Mission to Foreign Powers. New York: Charles

Scribner's Sons.

Hyman, Harold M. 1967. The Radical Republicans and Reconstruction, 1861-1870. Indianapolis: Bobbs-Merrill Press.

James M. Campbell \& Rebecca J. Fraser. 2008. Reconstruction: People and Perspectives. Santa Barbara: ABC-CLIO.

John Schrecker. 2010. "For the Equality of Men - For the Equality of Nations": Anson Burlingame and China's First Embassy to the United States, 1868. Journal of American-East Asian Relations 17 (2010) 9-34

Kraus, George. 1969. "Chinese Laborers and the Construction of the Central Pacific.” Utah Historical Quarterly 37(1): 41-57.

LI, Peter S. 1977. "Occupational mobility and kinship assistance: a study of Chinese immigrants in Chicago." Sociological Quarterly 18(4) (Autumn): 478-89.

Martin R. Ring. 1972. Anson Burlingame, S. Wells Williams and China, 1861-1870: A Great Era in Chinese-American Relations. Ph.D. diss., Tulane University Press.

McCunn, Ruthanne Lum. 1979. An Illustrated History of the Chinese in America, San Francisco : Design Enterprises of San Francisco.

Micah S. Muscolino. 2009. Fishing Wars and Environmental Change in Late Imperial and Modern China. Cambridge, Mass. Harvard University Press.

Milton, George Fort. 2004. The Age of Hate: Andrew Johnson and the Radicals. Dunning School: Kessinger Pub Co.,

Morton Keller. 1977. A $\square$ airs of State: Public Life in Late Nineteenth Century America. Cambridge, MA: Harvard University Press.

Palmer, Beverly Wilson. 1990. The Selected Letters of Charles Sumner: 1859-74. Northeastern University Press.

Perman, Michael and Amy Murrell Taylor. 2010. Major Problems in the Civil War and Reconstruction: Documents and Essays.

New York: The Granger Collection. Wadsworth: Cengage Learning. 
Reid, Whitelaw. 1866. After the war: a southern tour. May 1, 1865 to May 1, 1866. London: Sampson Low, Son, \& Marston. : $71,72,219,294,357$.

Simpson, Brooks D. 2016. "Mission Impossible: Reconstruction Policy Reconsidered.” Journal of the Civil War Era 6.1.: 85-102. Smith, Stacey L. 2016. "Beyond North and South: Putting the West in the Civil War and Reconstruction." Journal of the Civil War Era. Vol. 6, No. 4, The Civil War West: A Special Issue. University of North Carolina Press. : 566-591.

Stalcup, Brenda. 1995. Reconstruction: Opposing Viewpoints. Greenhaven Press.

Summers, Mark Wahlgren. 2014. The Ordeal of the Reunion: A New History of Reconstruction. Chapel Hill: UNC Press Books. Summers, Mark Wahlgren. 2009. A Dangerous Stir: Fear, Paranoia, and the Making of Reconstruction excerpt and text search. Chapel Hill: University of North Carolina Press.

Takaki, Ronald. 1998. Strangers From A Different Shore: A History of Asian Americans. New York: Back Bay Books.

Telly H. Koo. 1922. "The Life of Anson Burlingame." Ph.D. diss., Harvard University. : 20-44.

Thomas W. Chinn. 1969. A History of the Chinese in California: A Syllabus. San Francisco: Chinese Historical Society of America.

Walsh, Warren B. 2019. "The Beginnings of the Burlingame Mission”. The Far Eastern Quarterly, Vol. 4.31945.: 274-77.

https://www.jstor.org/stable/2049517?seq=1\#metadata_info_tab_contents

(accessed February 5, 2019)

Ward, Geoffrey. 1997. The West: An Illustrated History. Little, Brown \& Co.,

Weisberger, Bernard A. 1959. The dark and bloody ground of Reconstruction historiography. Indianapolis. Bobbs-Merrill.

William Archibald Dunning. 1907. Reconstruction: Political \& Economic, 1865-1877. New York: Harper and Brothers Publishers.

Woodward, C. Vann. 1991. Reunion and Reaction: the compromise of 1877 and the end of reconstruction. Oxford University Press. New York: Oxford University Press.

Wu, Y., Sun, I. Y., \& Smith, B. W. 2011. Race, Immigration, and Policing: Chinese Immigrants' Satisfaction with Police. JQ: Justice Quarterly, 28(5).

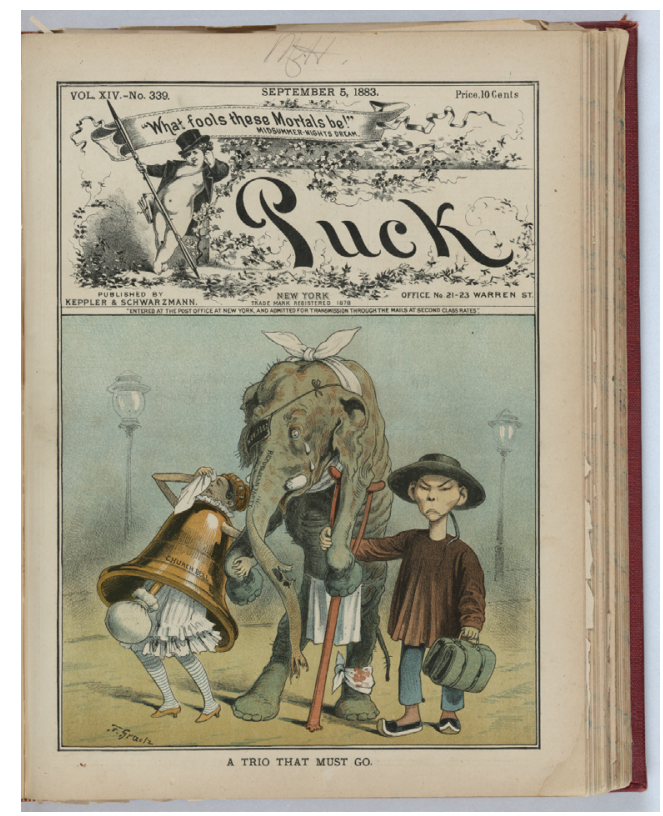

Figure 1: A trio that must go (Graetz F. 1883.) 